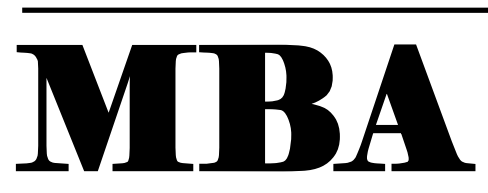

Vol. 5 , No. 1, January 2022, page 513 - 519

ISSN 2614-1981 (Print)

ISSN 2615-0352 (Online)

Journal of Management and Business Aplication

\title{
THE EFFECTIVENESS OF GOVERNMENT POLICY FOR MSMES IN SUPPORTING THE NATIONAL ECONOMIC RECOVERY IN JEMBER DISTRICT
}

\author{
Nely Supeni ${ }^{1}$ \\ Mustofa $^{2}$ \\ Mainatul IImi ${ }^{3}$ \\ Diana Dwi Astuti ${ }^{4}$
}

Sekolah Tinggi Ilmu Ekonomi Mandala, Jember ${ }^{l}$

Received : 2021/11/24 Corresponding author:

Revised : 2021/12/15 Name: Nely Supeni

Accepted : 2021/12/30 E-mail: nely@stie-mandala.ac.id

\begin{abstract}
This research is entitled Effectiveness of Government Policy for MSMEs in Supporting National Economic Recovery in Jember Regency. The purpose of this study was to determine whether the MSME Direct Cash Assistance (BLT) program in Jember Regency was effective and on target? This type of research is qualitative research, with 2 types of data used, namely primary data and secondary data. The total population is 1330 MSMEs and the sample used is 200 MSMEs. Analysis of the data used is descriptive qualitative analysis. The results of the study show that the Government's Policy for MSMEs in Supporting National Economic Recovery in the form of the MSME Direct Cash Assistance (BLT) program in Jember Regency has been effective, this can be seen from the three indicators used in the study, namely timeliness, accuracy in making choices., and target accuracy. Based on these three indicators, it shows that the BLT MSME Direct Cash Assistance program in Jember Regency is on time, has made the right choice, and is right on target.
\end{abstract}

Keywords: MSMEs, Government Policy, National Economic Recovery.

\section{INTRODUCTION}

Governor of Bank Indonesia, Perry Warjiyo said that there are 4 things that need to be considered regarding the recovery of the National Economy through Micro, Small and Medium Enterprises (MSMEs) that is:

1. There is a transmission of credit interest rate policies in the banking industry. This policy can be in the form of lowering loan interest rates for MSMEs. It is hoped that this reduction in 
interest rates will enable MSMEs to be able to pay secure loans from banks with light and not burdensome installments

2. There is a synergy between banks and the government as well as related stakeholders, such as the Ministry of Cooperatives and SMEs, Bank Indonesia to foster and empower MSME actors. This empowerment can be in the form of providing marketing training so that MSMEs are able to compete with competitors.

3. The Central Bank also continues to encourage various digitalization systems, including digitizing payment systems, digitizing banking, and digitizing MSMEs so that MSME products can be widely accessed by the public.

4. Inviting the Indonesian people to echo the national movement Proud to be Made in Indonesia campaign or love domestic products.

Based on some of the things above, it indirectly explains that MSMEs are at the forefront of helping the National Economic Recovery. Seeing that MSMEs are growing, it shows that people's purchasing power is increasing, indicating that the community's economy is getting better.

Micro, Small and Medium Enterprises must follow the trading system that is currently developing. This is in accordance with point 3 conveyed by the Governor of Bank Indonesia Perry Warjiyo, that the development of MSMEs is one of them by following the digitization system so that the products produced can be widely accessed by the public.

With the digital trade phenomenon that has made domestic MSMEs slump, plus the Covid19 pandemic which has a global impact on the world of trade, the government has paid more attention to MSMEs as the vanguard in the national economic recovery. This attention is in the form of a policy in the form of capital assistance for MSMEs.

The government policies for MSMEs above are implemented nationally simultaneously, automatically this is also implemented in Jember Regency. Through the Department of Cooperatives and MSMEs in Jember Regency, government policy programs can be channeled to MSMEs. Based on the policy given by the government to MSMEs, the purpose of this research is to find out whether the MSME Direct Cash Assistance (BLT) program in Jember Regency has been effective or on target.

\section{RESEARCH METHODS}

\section{Types of research}

This research is a qualitative research. Qualitative research is one type of research that uses respondents' arguments as the basis for obtaining in-depth information. Qualitative Research is a procedure in research that produces descriptive data in the form of written or spoken words from the behavior of people who can be observed (Moleong, 2014).

\section{Population, Sample and Sampling Technique}

According to Sugiyono (2013:115) the population is a generalization area consisting of: objects/subjects that have certain qualities and characteristics determined by researchers to be studied and then drawn conclusions. Population is a collection of subjects, variables, concepts, or phenomena. We can examine each member of the population to determine the nature of the population in question (Morissan, 2012). The population in this study were all MSMEs in Jember Regency in 2020, which were 1,330. Sampling technique if the total population is more than 1000 then the sample is taken at least $15 \%$ of the total population. So the number of samples taken in this study were 200 respondents. 
The sampling technique in this research is the snowball technique. The snowball technique is a sampling technique that begins with only one or two respondents, then information is obtained from these respondents to obtain further respondents. So with this snowball technique the number of respondents who were initially small will eventually increase until the number of samples needed by the researcher is met.

Snowball sampling technique is a method for identifying, selecting, and taking samples in a continuous network or chain of relationships. Researchers present a network through sociogram images in the form of images of circles that are linked or connected with lines. Each circle represents a response and/or case, and the lines show the relationship between respondents or between cases (Neuman, 2003).

\section{Method of collecting data}

The data collection method used in this study is a qualitative method that uses arguments as the basis for obtaining in-depth information to answer the research objectives. The focus of this research is on the effectiveness of capital assistance from the government for MSMEs in Jember Regency. The indicators used in this research are Punctuality, Accuracy in Making Choices, and Accuracy in Targets. Some of the methods used by researchers in collecting research data are:

\section{Interview}

Interview is one of the methods used by researchers to obtain data directly from respondents. According to Burhan Bungin (2012: 67) there are two types of interviews, namely structured interviews and in-depth interviews. Because 2021 is still in a pandemic condition, some interviews with respondents are conducted by telephone and some are conducted by meeting in person. This was done because there were some people who were still unwilling to meet with researchers for fear that the pandemic had not yet passed.

2. Media studies

Media studies are methods of collecting data through mass media, both electronic media, internet media and print media. Electronic media, namely by using television and radio, internet media using official websites related to research, print media in the form of newspapers. Some of these mass media are used by researchers to explore and obtain updated information regarding capital assistance from the government for MSMEs in Jember Regency.

\section{Data Types and Sources}

The data used in this study are primary data and secondary data. Primary data is data obtained directly from research subjects. In this research, this can be done through or in the form of distributing questionnaires to respondents. The researcher gave a statement to the respondent to be filled in according to what he experienced.

While secondary data is data obtained indirectly on the subject of research, or through intermediaries whose truth is no doubt. This can be in the form of financial statement data, company records or company evidence. In this study, secondary data was obtained through media studies and information from several related agencies, one of which was the official website https://kemenkopukm.go.id/.

Sources of data in this study obtained from interviews, and media studies. The media used are electronic media, internet media and print media. 


\section{Data analysis}

The method of qualitative descriptive analysis is to analyze, describe, and summarize various conditions, situations from various data collected in the form of interviews or observations about the problems studied that occur in the field (I Made Winartha, 2006). Analysis of the data used in this study is a qualitative descriptive analysis, namely an analysis that describes the results of the analysis that has been carried out. In qualitative research, the data obtained from respondents is in the form of information both verbally (arguments) and in writing, so that the essence of qualitative research is not numbers. The data obtained are then selected and filtered to make it easier to identify which data is needed and not needed in the study. After that the data that has been selected is described by the researcher in the form of text to make it easier for readers to understand. Finally, the researcher can draw a conclusion as well as answer the purpose of the research.

\section{RESULT ANALYSIS}

This research focuses on the effectiveness of the capital assistance program for MSMEs called Direct Cash Assistance (BLT) for MSMEs in Jember Regency. To answer the research objectives, measuring the effectiveness of the program, researchers used the indicators used by Makmur (2010:7) in Maun's research, CEF (2020), namely:

1. Timing accuracy: the time used appropriately will affect the level of effectiveness of a program or activity in achieving its goals.

2. Cost calculation accuracy: this is done so that in carrying out a program there is no shortage of funds or budget until the program is completed.

3. Accuracy in measurement: this means that in carrying out a program, standardization must be applied. The accuracy of the standards used in implementing a program is a measure of achieving effectiveness.

4. Accuracy in making choices: is an activity carried out for success in achieving goals because in making choices it takes a very important process to achieve effectiveness.

5. The accuracy of thinking can determine the effectiveness in achieving the goals that have been determined.

6. Accuracy in carrying out orders: is the activity of organizations or individuals who have the ability to give orders clearly and easily understood and if the orders given cannot be understood then the execution of the orders will fail and ultimately be ineffective.

7. Accuracy in setting goals: goals that are set correctly will support the effectiveness of the implementation of these activities.

8. Target accuracy: can determine the success of individual or organizational activities in achieving goals.

Of the eight indicators described above, not all indicators were used in this study. Researchers only use several indicators to answer the objectives of the study including indicators of Timeliness, Accuracy in determining Choices, and Accuracy of Targets.

After the researcher has obtained accurate data, it will be interpreted in depth in this chapter. The research results will be explained as follows:

\section{Punctuality}

Timeliness is one of the indicators to assess the effectiveness of a program. The implementation of such a program requires a planning in the form of determining the right implementation time, because if the timing is right, the program objectives will be obtained more 
effectively. Punctuality in distributing capital assistance in the form of Direct Cash Assistance (BLT) for MSMEs, must first identify MSMEs that are eligible to receive the capital assistance program. MSMEs that are eligible to receive are MSMEs that have met the requirements for recipients of assistance. Then the MSMEs that received capital assistance from the government received the month that had been promised by the cooperative office in collaboration with the banking sector in disbursing aid. Based on information received from MSMEs receiving assistance, the first disbursement was received by MSMEs amounting to 2,400,000 in December 2020, and the second disbursement of 1,200,000 in May 2021.

\section{Registration Process:}

Registration of recipients of Micro Business Productive Assistance (BPUM) or BLT UMKM can be done online or offline. If prospective beneficiaries register online, they must fill out the e-form provided. Meanwhile, if they are going to register offline, the MSMEs must come to the Small and Medium Enterprise Cooperatives Service (Diskop UKM) of Jember Regency to fill in administrative completeness.

The procedure for registering the $2021 \mathrm{MSME}$ Aid Assistance (https://www.liputan6.com/) is as follows:

1. MSME actors register themselves through the Cooperative Service and domicile MSMEs by attaching files in the form of KTP, KK, and Business Certificate or SKU or NIB.

2. Then, business actors are required to fill in the personal data form provided.

3. The process for applying for BLT UMKM or BPUM assistance will be verified by the Cooperatives and UMKM Office and related agencies or institutions.

4. If the application for BPUM or BLT MSMEs of Rp. 1.2 million is received, then the business actor will receive a notification from the Cooperatives and MSME Service.

If the registrant MSMEs meet the requirements above and are designated as recipients of BPUM or MSME BLT, they will receive SMS from BNI and BRI to disburse their assistance. If they do not receive an SMS, the beneficiary MSME can check the list of beneficiaries at the link eform.bri.co.id or banpresbpum.id ((https://www.liputan6.com/). Then during the disbursement process, the bank will immediately help create an account.

\section{Verification Process}

The verification process is a process where the Department of Cooperatives and SMEs of Jember Regency selects and determines the eligible MSMEs to be designated as recipients of BPUM or BLT MSME assistance based on the completeness of the data submitted by MSMEs. This process, of course, requires time and accuracy of officers in determining who is eligible to receive assistance, because there are so many MSMEs that have registered for this program.

Based on information obtained from MSME recipients of BPUM or BLT MSME assistance, the disbursement of the assistance was timely because MSME recipients of assistance could withdraw the aid money after they received information via SMS if they were the beneficiary. receive an SMS which states that the MSME is a recipient of BPUM or BLT MSMEs, and if the MSME recipients do not have a BNI or BRI bank account, then they just have to come to the bank and the bank will help create an account. After the account creation is complete, the money can also be directly taken by MSMEs

\section{Accuracy in Making Choices}

The process of making choices is certainly not an easy thing for the SME Diskop of Jember Regency, because there are many who register as candidates for BPUM or BLT UMKM 
assistance, both online and offline. The SME Diskop of Jember Regency must be really careful in determining the MSMEs that meet the requirements, completing all the stipulated requirements.

Based on the information obtained by the researchers, there were several MSMEs in the Tanjung Jember market that were declared recipients of BPUM or BLT MSME assistance even though they felt they did not register. After the researchers dug deeper information, it turned out that the MSMEs had been registered by the Tanjung Market Service. So at the time of registration, the Tanjung market office immediately recorded and entered the administrative completeness of the Tanjung market MSMEs to the Jember District SME Diskop. Then the Kadiskop UKM Jember Regency continued to check the completeness of the requirements and they were sure of the UMKM-UMKM submitted by the Tanjung Market Service that the data submitted were indeed SMEs in the Tanjung Jember market. Then the MSMEs are declared as recipients of assistance.

So the determination of several Tanjung market SMEs as recipients is not without going through a registration process, they also go through a selection process, but they are brought through the Tanjung Jember Market Service.

Based on this information, it can be stated that the Department of Cooperatives and SMEs of Jember Regency is right in determining the choice of UMKM-UMKM which is stated to be the cause for recipients of BPUM or BLT UMKM assistance.

\section{Target Accuracy}

Ensuring the accuracy of the target, the researcher refers to the conditions used as a benchmark in determining which MSMEs are entitled to receive assistance from BPUM or BLT MSMEs. Because in these requirements it is clear that the proper MSMEs are MSMEs that actually exist (not fake), and have been operating their business. This is evidenced by the existence of a Business Certificate (SKU) or Business Identification Number (NIB).

From the side of the officers who verify the MSME data for prospective beneficiaries, they are a team from the Jember Regency Cooperatives and SMEs Service which has been clear in determining the MSME recipients of assistance, and has also been approved by the Head of the Small and Medium-sized Enterprises of Jember Regency. The requirements that must be met by MSMEs are absolute and must be met, so that if they are not declared as recipients of this assistance, it could be because the number of registrants is too large, so the Diskop team will still filter from all registrants or indeed MSMEs who register do not meet the requirements. that has been determined by the Diskop and UKM of Jember Regency. Based on the above, it can be said that the capital assistance program in the form of Direct Cash Assistance (BLT) for SMEs in Jember Regency is right on target.

\section{CONCLUSION}

Based on the results of the research described above, it can be concluded that the Government's Policy for MSMEs in Supporting National Economic Recovery in the form of the MSME Direct Cash Assistance (BLT) program in Jember Regency has been effective, this can be seen from the three indicators used in The research is based on indicators of timeliness, accuracy in making choices, and accuracy of targets. Based on the three indicators used, it shows that this program:

1. It is timely because during the current pandemic, MSMEs, which are one of the vanguard in supporting national development, really need the government's role in assisting MSMEs in continuing their business. 
2. It is appropriate in determining which MSMEs are eligible to receive the assistance program, because MSMEs receiving assistance are MSMEs that have met the requirements as recipients of assistance.

3. It is right on target because this program has made the right choice, so that it means that those who are declared as recipients of the program assistance are really MSMEs that deserve to receive assistance.

\section{IMPLICATIONS}

Based on the results of the research that has been carried out, and seeing the benefits of the MSME Direct Cash Assistance (BLT) program in Jember Regency for MSMEs, the researchers suggest to the government through the Jember Regency Cooperatives and SMEs Service to be able to carry out the MSME Cash Direct Assistance (BLT) program in the District. Jember sustainably or sustainably, this is intended so that MSMEs in Jember district can survive and can develop their businesses to support national development in Indonesia.

\section{REFERENCES}

A., Morissan M., dkk. (2012). Metode Penelitian Survei. Jakarta: Kencana Burhan Bungin. 2012. Analisa Data Penelitian Kualitatif. Jakarta: Rajawali Pers.

I Made Wirartha. 2006. Pedoman Penulisan Usulan Penelitian, Skripsi dan Tesis. Yogyakarta: Andi.

J. Moleong, Lexy. 2014. Metode Penelitian Kualitatif, Edisi Revisi. Bandung: PT Remaja Rosdakarya.

Makmur. 2011. Efektivitas Kebijakan Kelembagaan Pengawasan. Bandung: PT. Refika Aditama

Maun, C. E. 2020. Efektivitas Bantuan Langsung Tunai Dana Desa Bagi Masyarakat Miskin Terkena Dampak Covid-19 Di Desa Talaitad Kecamatan Suluun Tareran Kabupaten Minahasa Selatan. Jurnal Politico, 9(2).

Neuman, W. L. (2003). Social Research Methods, Qualitative and Quantitative Approaches. Fifth Edition. Boston: Pearson Education.

Sugiyono. 2013. Metode Penelitian Kuantitatif, Kualitatif dan R\&D. Bandung: Alfabeta.CV Sugiyono. 2018. Metode Penelitian Kuantitatif. Bandung: Alfabeta.

https://www.cnbcindonesia.com/market/20210415171235-17-238218/ini-4-kunci-dari-gubernurbi-untuk-pemulihan-ekonomi-ri (accessed on Thursday, April 15, 2021, at $03.00 \mathrm{pm}$ )

https://www.cnbcindonesia.com/news/20210304135255-4-227842/jokowi-ungkap-marketplacebunuh-umkm-ternyata-ini-pemicunya (accessed on Maret 4, 2021 at $02.30 \mathrm{pm}$ ).

https://idcloudhost.com/pengertian-umkm-menurut-undang-undang-kriteria-dan-ciri-ciri-umkm/ (accessed on April 19, 2021 at $03.00 \mathrm{pm}$ )

https://ekonomi.bisnis.com/read/20210209/259/1354196/ada-6-insentif-pajak-buat-karyawanhingga-umkm-sampai-juni-2021 (accessed on April 19, 2021 pukul 03.00 pm)

https://produkumkmjember.id/anggota (accessed on April 12, 2021 jam $09.00 \mathrm{am}$ )

https://www.liputan6.com/bisnis/read/4631627/simak-cara-daftar-bpum-umkm-2021 (accessed on Desember 15, 2021 jam 11.35 am). 